\title{
Does Knowing Someone with Breast Cancer Influence the Prevalence of Adherence to Breast and Cervical Cancer Screening?
}

\section{Conhecer alguém com câncer de mama influencia a prevalência da adesão ao rastreamento dos cânceres de} mama e colo uterino?

\author{
Igor Vilela Brum ${ }^{1}$ Tamara Cristina Gomes Ferraz Rodrigues ${ }^{1} \quad$ Estela Gelain Junges Laporte ${ }^{1}$ \\ Fernando Monteiro Aarestrup ${ }^{1}$ Geraldo Sergio Farinazzo Vitral ${ }^{1}$ Bruno Eduardo Pereira Laporte ${ }^{1}$ \\ ${ }^{1}$ Hospital Universitário, Universidade Federal de Juiz de Fora, \\ Juiz de Fora, MG, Brazil \\ Rev Bras Ginecol Obstet 2018;40:203-208. \\ Address for correspondence Bruno Eduardo Pereira Laporte, MD, \\ MSc, Universidade Federal de Juiz de Fora, Rua José Lourenço Kelmer, \\ s/n, 36036-330, Juiz de Fora, MG, Brazil \\ (e-mail: laportebruno@hotmail.com).
}

\begin{abstract}
Keywords

- mass screening

- breast neoplasms

- breast selfexamination

- uterine cervical neoplasms

- public health

Objective To evaluate the prevalence of adherence to screening methods for breast and cervical cancer in patients attended at a university hospital and to investigate whether knowing someone with breast cancer, moreover belonging to the patient's family, affects the adherence to the screening recommendations.

Methods This was a cross-sectional and quantitative study. A structured interview was applied to a sample of 820 women, between 20 and 69 years old, who attended a university hospital in the city of Juiz de for a, MG, Brazil. For the analysis, the chi-square test was used to assess possible associations between the variables, and the significance level was set at $p$-value $\leq 0.05$ for a confidence interval $(\mathrm{Cl})$ of $95 \%$.

Results More than $95.0 \%$ of the sample performed mammography and cervical cytology exam; $62.9 \%$ reported knowing someone who has or had breast cancer, and this group was more likely to perform breast self-examination (64.9\%; odds ratio [OR] 1.5; 95\% Cl 1.12-2.00), clinical breast examination (91.5\%; OR 2.11; 95\% Cl 1.37-3.36), breast ultrasound (32.9\%; OR $1.81,95 \% \mathrm{Cl} 1.30-2.51)$, and to have had an appointment with a breast specialist (28.5\%; OR $1.98,95 \% \mathrm{Cl} 1.38-2.82)$. Women with family history of breast cancer showed higher propensity to perform breast self-examination (71.0\%; OR 1.53 95\% Cl 1.04-2.26).

Conclusion There was high adherence to the recommended screening practices; knowing someone with breast cancer might make women more sensitive to this issue as they were more likely to undergo methods which are not recommended for the screening of the general population, such as breast ultrasound and specialist consultation; family history is possibly an additional cause of concern.
\end{abstract}

received

July 20, 2017

accepted

December 12, 2017

published online

April 2, 2018
DOI https://doi.org/

10.1055/s-0038-1623512.

ISSN 0100-7203.
Copyright ( $\odot 2018$ by Thieme Revinter

Publicações Ltda, Rio de Janeiro, Brazil
License terms

(c) $(1) \$$ 


\section{Resumo}

Palavras-chave
- programas de
rastreamento
- neoplasias da mama
- autoexame de mama
- neoplasias do colo do
útero
- saúde pública

Objetivos Avaliar a prevalência da adesão aos métodos de rastreamento dos cânceres de mama e de colo uterino em pacientes atendidas em um hospital universitário e investigar se conhecer alguém com câncer de mama e, o fato de este pertencer à família, modifica a adesão às recomendações de rastreamento.

Métodos Estudo transversal e quantitativo. Uma entrevista estruturada foi aplicada a uma amostra de 820 pacientes do sexo feminino, entre 20 e 69 anos, usuárias de um hospital universitário na cidade de Juiz de Fora, MG. Para a análise, o Teste Quiquadrado foi usado para avaliar a possibilidade de associação entre as varáveis, e o valor de significância foi determinado em valor- $p \leq 0,05$ para um intervalo de confiança (IC) de $95 \%$.

Resultados Mais de $95,0 \%$ da amostra realizava os exames de mamografia e colpocitologia; $62,9 \%$ relataram conhecer alguém que teve ou tem câncer de mama, sendo que este grupo realizou, com maior frequência, autoexame (64,9\%; razão de prevalência [RP] 1,5; IC 95\% 1,12-2,00), exame clínico (91,5\%; RP 2,11; IC 95\% 1,37$3,36)$ e ultrassonografia das mamas (32,9\%; RP 1,81, IC 95\% 1,30-2,51) e consulta ao mastologista (28,5\%; RP 1,98, IC 95\% 1,38-2,82). Mulheres com história familiar de câncer de mama realizaram com maior prevalência o autoexame das mamas (71,0\%; RP 1,53 IC 95\% 1,04-2,26).

Conclusão A amostra apresentou elevada adesão aos métodos de rastreamento preconizados; conhecer alguém com câncer de mama pode tornar as mulheres mais sensíveis a essa questão, aumentando a realização de medidas não recomendadas para o rastreamento da população geral, como ultrassonografia das mamas e consulta com médico especialista; a história familiar possivelmente implica em um fator de preocupação adicional.

\section{Introduction}

Breast cancer is the second most common malignant neoplasm among women in Brazil, as well as in the world, being surpassed only by non-melanoma skin cancer. ${ }^{1,2}$ In addition to its high prevalence, it is also a source of anxiety and fear for patients, since the primary treatment of this type of cancer is based on the surgical excision of the lesion, sometimes causing mutilations and affecting women's self-image. ${ }^{3}$

After the diagnosis of breast cancer, the patient might face feelings of guilt, anguish, pain, and suffering, as well as doubts about the success of the treatment, and fear of dying. Anxiety, depression, reduced libido, physical discomfort and low self-esteem are some of the situations experienced by patients with cancer, provoking profound changes throughout their lifetime. ${ }^{4-7}$

It is also known that these repercussions go beyond the patient herself, also affecting the women who live around her. ${ }^{8,9}$ More than $40 \%$ of women know someone with breast cancer, and a study showed that these women had a better knowledge and perception of the disease. ${ }^{10,11}$ Women with heightened perceptions of breast cancer risk are more likely to take actions to gain a sense of control over the disease, leading to a higher prevalence of mammography screening, genetic testing, and prophylactic mastectomy. ${ }^{12,13}$ Lack of information about cancer, misunderstanding of risk factors or screening guidelines, and inaccurate perception of cancer risk may also affect the individual's behavior toward other types of cancer, such as cervical and colon cancer. ${ }^{14}$ Few studies, however, have investigated whether these repercussions instill changes in attitudes and behaviors, leading women, for example, to greater adherence to guidelines for screening of breast and cervical cancer. ${ }^{15}$ Determining the factors that influence the adherence to cervical cancer screening measures is also important as it remains the third most prevalent type of cancer among women in Brazil. ${ }^{1}$

The Brazilian Ministry of Health recommends that breast cancer screening for the general female population, meaning women without high risk for such neoplasm, should consist of bi-annual mammography (MMG) between the ages of 50 and 69 years old. ${ }^{16}$ It also recommends clinical breast examinations ( $\mathrm{CBE}$ ) as part of the integral care for women's health, and breast self-examination (BSE) as an educational health action, encouraging women to gain knowledge about their own bodies. $^{16,17}$ Screening for cervical cancer and its precursor lesions, in turn, consists of a cytological examination, which should begin at the age of 25 for women who have had sexual activity, and it should continue until the age of $64 .^{16}$

This study aims to evaluate the prevalence of adherence to screening methods for breast and cervical cancers in patients attended at a university hospital. Additionally, we sought to investigate whether knowing someone with breast cancer, moreover belonging to the patient's family, would effectively instill a greater adherence to cancer screening recommendations. 


\section{Methods}

A cross-sectional, quantitative and descriptive field study was performed. The purpose of the study was to assess the possible associations between knowing someone who has had or currently has breast cancer with the adherence to screening measures for breast and cervical cancers. ${ }^{16}$

The sample consisted of 820 female patients, with ages ranging from 20 to 69 years old, attended at a university hospital in the city of Juiz de Fora, MG, Brazil. The minimum sample size was estimated in 820 women, based on a simple random sampling, with a confidence level of $95.0 \%$ and a sampling error of $5.0 \%$. Women with a personal history of breast cancer were excluded from this study. A total of 861 patients were invited to respond the questionnaire, 41 of whom refused to participate (refusal rate $4.7 \%$ ). The data collection was performed during the working hours of the hospital's different outpatient clinics, while the patients were in the waiting room. They were assigned a random number that was electronically generated.

The data was collected through an interview application composed by 43 questions, which were based on the specialized literature about the subject and elaborated by the authors of this research. To cover the points of interest in this study, five questions were asked regarding the socioeconomic profile of the sample, as well as two questions about whether or not someone with breast cancer is known, and six questions regarding adherence to screening measures and other complementary tests.

The study's exposure variables were: 1 . knowing someone who has had or currently has breast cancer; 2 . if this known individual belonged to the family of the research participant. The outcome variables consisted in the completion or not of the screening measures as recommended by the Brazilian Ministry of Health: 1. BSE; 2. CBE; 3. MMG for women between 50 and 69 years old; 4 . cervical cytology, for women between 25 and 64 years of age. In addition to these variables, the following were evaluated: 5 . consultation with a breast specialist; 6 . to have performed a breast ultrasound (BUS).

Additionally, to carry out the analysis of the association between the variables, the chi-square test of independence (without correction) was applied. The significance level was p-value $\leq 0.05$ for a confidence interval of $95.0 \%$. Furthermore, the Statistical Package for The Social Sciences (SPSS) version 15.02006 software (SPSS Inc., Chicago, IL, USA) was used to construct the database and the statistical analysis. The approach was done by researchers, the authors of this study, who were previously trained, and the study was approved by the institution's ethics committee under the number 156.162 .

\section{Results}

The mean age of the patients in the sample was 42.6 years of age (standard deviation [SD]: \pm 12.8 ), 44.5 years old among the interviewees who knew someone with breast cancer, and 39.4 among those who did not know it $(p<0.01)$. The majority of the sample had completed a secondary/technical or undergraduate education (53.0\%), presented monthly
Table 1 Distribution of the sociodemographic characteristics of the sample

\begin{tabular}{|c|c|}
\hline Variables & n (\%) \\
\hline \multicolumn{2}{|l|}{ Age } \\
\hline 20 to 39 & $356(43.4)$ \\
\hline 40 to 44 & $105(12.8)$ \\
\hline 45 to 69 & $359(43.8)$ \\
\hline \multicolumn{2}{|l|}{ Educational level } \\
\hline Illiterate/incomplete elementary school & $9(1.1)$ \\
\hline $\begin{array}{l}\text { Completed elementary } \\
\text { school/completed high school }\end{array}$ & $376(45.9)$ \\
\hline $\begin{array}{l}\text { Completed high school or technical } \\
\text { school/incomplete } \\
\text { undergraduate education }\end{array}$ & $339(41.3)$ \\
\hline Complete undergraduate education & $96(11.7)$ \\
\hline \multicolumn{2}{|l|}{ Monthly family income (minimum wages) } \\
\hline$\leq 2$ & $448(54.6)$ \\
\hline$>2$ and $\leq 4$ & $307(37.4)$ \\
\hline$>4$ & $65(8.0)$ \\
\hline \multicolumn{2}{|l|}{ Living área } \\
\hline Rural area & $762(92.9)$ \\
\hline Urban area & $58(7.1)$ \\
\hline \multicolumn{2}{|l|}{ Marital status } \\
\hline Single & $242(28.5)$ \\
\hline Married/Stable union & $454(55.4)$ \\
\hline Separated/Divorced & $78(9.5)$ \\
\hline Widow & $46(5.6)$ \\
\hline
\end{tabular}

family income lower than 2 minimum wages (54.6\%), lived in urban areas (92.9\%) and were married or in a stable union (55.4\%) (-Table 1).

It is noteworthy to mention that, in the analyzed sampling, a rate of $62.9 \%$ reported knowing someone who has had or currently has breast cancer and, among this group of women, $35.5 \%$ stated that such patient belonged to their own family.

Statistically, higher rates of the BSE and CBE implementation were observed among those people interviewed who reported having known someone who had or has breast cancer. If we compared them to those women who did not know someone diagnosed with breast cancer, the same fact was not observed in relation to MMG and cervical cytology, which presented a fulfilment rate higher than $94.0 \%$ in both researched groups (-Table $\mathbf{2}$ ).

Additionally, a rate of $28.5 \%(n=147)$ of the women who knew someone with breast cancer had already consulted a breast specialist and 32.9\% $(n=170)$ had already performed a breast USG. The same fact was observed in $16.8 \%(n=51$, $p<0.01, \quad$ OR $=1.98,95 \% \quad \mathrm{CI} 95 \%=1.38-2.82)$ and $21.4 \%$ ( $n=65, p<0.01, \mathrm{OR}=1.81, \mathrm{CI} 95 \%=1.30-2.51)$ of the women who did not report having such knowledge. 
Table 2 The correlation between knowing someone with breast cancer or not and adherence to the screening measures

\begin{tabular}{|l|l|l|l|l|}
\hline \multirow{2}{*}{ Screening } & \multicolumn{4}{|l|}{ Do you know someone with breast cancer? } \\
\cline { 2 - 5 } & Yes $\mathbf{n}(\%)$ & No $\mathbf{n}(\%)$ & $p$ & OR (CI 95\%) \\
\hline BSE & $335(64.9)$ & $168(55.3)$ & 0.01 & $1.50(1.12-2.00)$ \\
\hline CBE & $472(91.5)$ & $254(83.6)$ & $<0.01$ & $2.11(1.37-3.26)$ \\
\hline MMG (> 50 years) & $201(97.6)$ & $65(95.6)$ & 0.40 & $1.90(0.43-7.98)$ \\
\hline Colpocytology (25 to 64 years) & $434(95.4)$ & $245(94.6)$ & 0.63 & $1.18(0.59-2.36)$ \\
\hline
\end{tabular}

Abbreviations: BSE, breast self-examination; CBE, clinical breast examination; IC, confidence interval; MMG, mammography; OR, odds ratio. $\mathrm{n}=820 ;{ }^{*} \mathrm{n}=274 ;{ }^{*} \mathrm{n}=714$.

A higher prevalence of BSE was observed in patients with a family history of breast cancer in relation to the group of women that knew a person diagnosed with cancer who did not belong to their family. Furthermore, no significant differences were observed regarding the adherence to the other screening measures studied herein ( - Table 3 ). It was also observed that in the first group, a rate of $31.1 \%$ women $(n=57)$ had already consulted the specialist and $37.2 \%$ ( $n=68)$ performed a breast USG. The same was observed in $27.0 \%(n=90, p=0.32, \mathrm{OR}=1.22, \mathrm{Cl}=0.82-1.81)$ and $30.6 \%$ $(n=102, p=0.13, \mathrm{OR}=1.34, \mathrm{CI}=0.92-1.96)$, respectively, in the second group.

\section{Discussion}

The present study described the adherence to screening measures recommended for breast and cervical cancers based on knowing or not knowing someone who was diagnosed with breast cancer, and also, in positive case, if the known individual was a family member. It is noteworthy to mention that more than $60.0 \%$ of the sample knew someone who had or currently has breast cancer, and this knowledge implied a higher fulfillment of BSE and CBE, while the first one was performed in an even higher proportion in cases with a family history.

There is an estimation of 58 thousand breast cancer cases each year in Brazil, corresponding to an incidence of 56.2 new cases per 100,000 women. ${ }^{1}$ Thus, due to the high prevalence of the disease, it is expected that a considerable proportion of women know patients who had or have such neoplasm. There are few data available about the prevalence of this knowledge among women, ranging from 40 to $63 \% .{ }^{10,18,19}$ Therefore, the prevalence of women who know someone with breast cancer can be considered elevated in this study. The authors did not find previous Brazilian statistics about it.

It is known that psychological variables make an important contribution to whether an individual seeks cancer screening. ${ }^{20}$ Some authors have suggested that a concern of breast cancer is beneficial, since it would lead women to adopt a more proactive attitude toward cancer screening. ${ }^{21,22}$ However, others have advocated that such feelings would conduct women to avoid screening for fear of the diagnosis. ${ }^{23,24}$ Although we have not directly assessed the psychological impact of knowing someone with breast cancer, one way to understand the results in the study herein might be in accordance with this first point of view, since a higher completion of BSE and CBE among women who reported knowing patients who had or have breast cancer was identified.

On the other hand, it is possible that such urgency may occur excessively, since, in this group, a higher proportion of submission to BUS and consultations with the breast specialist were also observed. Such actions, which are not considered effective initial methods of breast cancer screening for the general population, may generate negative consequences if performed, such as additional costs, besides the physical impact as an unnecessary biopsy and psychological shock in cases of false-positive results. ${ }^{22,25}$

A family member diagnosed with breast cancer seems to be an additional factor of concern, revealing itself in this study by the greater completion of BSE by women with a history of such disease in the family. This information, again, corroborates with the fact that the fear of diagnosis does not lead women to avoid it, insofar as the family history did not prove to be an impediment to the adherence to the appropriate screening measures.

Table 3 Correlation between family history of breast cancer and adherence to screening measures in the group of women who knew someone who had or has breast cancer

\begin{tabular}{|l|l|l|l|l|}
\hline \multirow{2}{*}{ Screening } & \multicolumn{4}{|l|}{ Family history of breast cancer? } \\
\cline { 2 - 5 } & Yes $\mathbf{n}(\%)$ & No $\mathbf{n}(\%)$ & $p$ & OR (CI 95\%) \\
\hline BSE & $130(71.0)$ & $205(61.6)$ & 0.03 & $1.53(1.04-2.26)$ \\
\hline CBE & $170(92.9)$ & $302(90.7)$ & 0.39 & $1.34(0.68-2.63)$ \\
\hline MMG (> 50 years) & $65(98.5)$ & $136(97.1)$ & 0.56 & $1.91(0.21-17.45)$ \\
\hline Colpocytology (25 to 64 years) $^{*}$ & $157(96.3)$ & $277(94.9)$ & 0.48 & $1.42(0.54-3.73)$ \\
\hline
\end{tabular}

Abbreviations: BSE, breast self-examination; CBE, clinical breast examination; Cl, confidence interval; MMG, mammography; OR, odds ratio. $n=820 ;{ }^{*} n=206 ;{ }^{*} n=455$. 
In this scenario, health professionals are important to assist and educate women to minimize their apprehensions and deconstruct myths that exist around breast and cervical cancers. This is necessary, mainly, because the majority of women acquire information about screening measures through layman sources, such as television. ${ }^{26}$ Misconceptions about cancer and risk factors can influence behavior toward other types of cancers; however, in this study, knowing someone with breast cancer did not affect cervical cancer screening, possibly due to the high adherence to the recommended practices.

Besides the psychological consequences, knowing someone with breast cancer can influence adherence to screening methods through other ways. For instance, beliefs about the effectiveness and importance of the diagnostic methods, perceived risk of cancer, attitudes toward the healthcare providers, and higher knowledge about the disease can play a role in women's decision to adhere or not to the screening recommendations. ${ }^{10-14,20}$ Those aspects, however, were not assessed in this study and should be further investigated.

A positive finding of this study was that, among the recommended age groups by the Brazilian Ministry of Health, in the group researched at the university hospital, a rate of 97.1\% reported having done a MMG, and more than $95.1 \%$ had undertaken cervical cytology examination. These values are higher than the World Health Organization goals, as well as the national coverage, which are 70.0 and $60.0 \%$, respectively, for MMG, and 80.0 and $79.4 \%$ for colpocytology. ${ }^{27}$

The fact that the study sample comes from a university hospital limits the comparison of the results with the Brazilian general population, since all these women receive healthassistance. Furthermore, the prevalence was estimated based on the patients' reports, so it was not possible to verify the performance of the screening methods. Another limitation is the fact that some patients, who may have been considered to be at high risk of having breast cancer and, therefore, should have their screening individualized, may have been analyzed within the recommendations for the general population.

On the other hand, due to the fact that knowing someone with breast cancer may lead to a greater completion of the BSE, CBE and BUS, as well as conduct to consultations with the breast specialist, the present study highlights the health professionals' importance in the assistance and orientation of these patient groups. Additionally, it also serves as a theoretical support for researches that may provide a more comprehensive understanding of the emotional dynamics involved behind the greater search for the screening methods and early diagnosis by women with this context of life.

\section{Conclusion}

Knowing someone with breast cancer makes women more sensitive to this issue, which possibly justifies the increase in the implementation of BSE and CBE. The broad coverage of MMG and cervical cytology examinations proved to be important in ensuring that women have access to the main methods of screening, independently of their individual aspects. Finally, considering that most women know a breast cancer patient, health services should be adequate to accommodate and work more effectively on the apprehensions of this group of women.

\section{Contributions}

Brum I. V., Rodrigues T. C. G. F., Laporte E. G. J., Aarestrup F. M., Vitral G. S. F. and Laporte B. E. P. contributed with the project and interpretation of data, writing of the article, critical review of the intellectual content and final approval of the version to be published.

\section{Conflicts to Interest}

The authors of this article declared they have no conflicts of interest.

\section{References}

1 Ministério da Saúde. Instituto Nacional de Câncer José Alencar Gomes da Silva. Estimativa 2016: Incidência de Câncer no Brasil. Rio de Janeiro, RJ: INCA; 2015. http://www.inca.gov.br/estimativa/ 2016/estimativa-2016-v11.pdf. Acessado Junho 27, 2016

2 Torre LA, Bray F, Siegel RL, Ferlay J, Lortet-Tieulent J, Jemal A. Global cancer statistics, 2012. CA Cancer J Clin 2015;65(02): 87-108. Doi: 10.3322/caac.21262

3 Almeida RA. Impacto da mastectomia na vida da mulher. Rev SBPH (Belo Horizonte) 2006;9:99-113

4 Deitos TFH, Gaspary JFP. Efeitos biopsicossociais e psiconeurológicos do câncer sobre pacientes e familiares. Rev Bras Cancerol 1997;43:117-126

5 Sampaio AC. Mulheres com Câncer de Mama: Análise Funcional do Comportamento Pós-Mastectomia [dissertation]. Campinas, SP: Pontifícia Universidade Católica de Campinas; 2006

6 Kornblith AB, Herndon JE II, Zuckerman E, et al; Cancer and Leukemia Group B. Social support as a buffer to the psychological impact of stressful life events in women with breast cancer. Cancer 2001;91(02):443-454

7 Gonçalves SROS, Arrais FMA, Fernandes AFC. As implicações da mastectomia no cotidiano de um grupo de mulheres. Rev Rene 2016;8:9-17. Doi: 10.15253/rev\%20rene.v8i2.5280

8 Tavares JSC, Trad LAB. Famílias de mulheres com câncer de mama: desafios associados com o cuidado e os fatores de enfrentamento. Interface 2009;13:395-408. Doi: 10.1590/S1414-328320090002 00012

9 Bervian PI, Girardon-Perlini NMO. A família (con)vivendo com a mulher/mãe após a mastectomia. Rev Bras Cancerol 2006; 52:121-128

10 Sim HL, Seah M, Tan SM. Breast cancer knowledge and screening practices: a survey of 1,000 Asian women. Singapore Med J 2009; 50(02):132-138

11 Powe BD, Daniels EC, Finnie R, Thompson A. Perceptions about breast cancer among African American women: do selected educational materials challenge them? Patient Educ Couns 2005;56(02):197-204. Doi: 10.1016/j.pec.2004.02.009

12 Katapodi MC, Lee KA, Facione NC, Dodd MJ. Predictors of perceived breast cancer risk and the relation between perceived risk and breast cancer screening: a meta-analytic review. Prev Med 2004;38(04):388-402. Doi: 10.1016/j.ypmed.2003.11.012

13 Hay JL, McCaul KD, Magnan RE. Does worry about breast cancer predict screening behaviors? A meta-analysis of the prospective evidence. Prev Med 2006;42(06):401-408. Doi: 10.1016/j. ypmed.2006.03.002 
14 Kim SE, Pérez-Stable EJ, Wong S, et al. Association between cancer risk perception and screening behavior among diverse women. Arch Intern Med 2008;168(07):728-734. Doi: 10.1001/archinte.168.7.728

15 Salci MA, Marcon SS. De cuidadora a cuidada: quando a mulher vivencia o câncer. Texto Contexto Enferm 2008;17:544-551. Doi: 10.1590/S0104-07072008000300016

16 Ministério da Saúde. Secretaria de Atenção à Saúde. Departamento de Atenção Básica. Controle dos Cânceres do Colo do Útero e da Mama. 2ª ed. Brasília, DF: Ministério da Saúde; 2013

17 Ministério da Saúde. Instituto Nacional de Câncer. Coordenação de Prevenção e Vigilância. Controle do Câncer de Mama: Documento de Consenso. Rio de Janeiro, RJ: INCA; 2004

18 Powe BD, Hamilton J, Brooks P. Perceptions of cancer fatalism and cancer knowledge: a comparison of older and younger African American women. J Psychosoc Oncol 2006;24(04):1-13. Doi: 10.1300/J077v24n04_01

19 Padela AI, Murrar S, Adviento B, et al. Associations between religion-related factors and breast cancer screening among American Muslims. J Immigr Minor Health 2015;17(03):660-669. Doi: 10.1007/s10903-014-0014-y

20 George SA. Barriers to breast cancer screening: an integrative review. Health Care Women Int 2000;21(01):53-65. Doi: 10.1080/073993300245401

21 Diefenbach MA, Miller SM, Daly MB. Specific worry about breast cancer predicts mammography use in women at risk for breast and ovarian cancer. Health Psychol 1999;18(05):532-536. Doi: 10.1037/0278-6133.18.5.532

22 McCaul KD, Reid PA, Rathge RW, Martinson B. Does concern about breast cancer inhibit or promote breast cancer screening? Basic Appl Soc Psych 1996;18:183-194. Doi: 10.1207/ s15324834basp1802_5

23 Kash KM, Holland JC, Halper MS, Miller DG. Psychological distress and surveillance behaviors of women with a family history of breast cancer. J Natl Cancer Inst 1992;84(01):24-30

24 Andersen MR, Smith R, Meischke H, Bowen D, Urban N. Breast cancer worry and mammography use by women with and without a family history in a population-based sample. Cancer Epidemiol Biomarkers Prev 2003;12(04):314-320

25 Consedine NS, Magai C, Krivoshekova YS, Ryzewicz L, Neugut AI. Fear, anxiety, worry, and breast cancer screening behavior: a critical review. Cancer Epidemiol Biomarkers Prev 2004;13(04): 501-510

26 Rodrigues TCGF, Brum IV, Santos JLT, Juste AM, Laporte EGJ, Laporte BEP. Conhecimento de 820 mulheres atendidas no Hospital Universitário da Universidade Federal de Juiz de Fora sobre autoexame das mamas. Rev Bras Mastologia 2016;26:60-64. Doi: $10.5327 / Z 201600020006$

27 Instituto Brasileiro de Geografia e Estatística. Pesquisa Nacional de Saúde: 2013: Ciclos de Vida: Brasil e Grandes Regiões. Rio de Janeiro, RJ: IBGE; 2015 